\title{
Earth history along Colorado's Front Range: Salvaging geologic data in the suburbs and sharing it with the citizens
}

\author{
Robert G. Raynolds, Kirk R. Johnson, Beth Ellis, Marieke \\ Dechesne, and Ian M. Miller, Denver Museum of Nature \& \\ Science, 2001 Colorado Boulevard, Denver, Colorado, \\ 80205, USA
}

\begin{abstract}
The Denver Basin preserves $>800 \mathrm{~m}$ of Laramide synorogenic strata, which record basin accommodation, orogenic topography, and resultant orographic climatic effects. The basin also records the Cretaceous-Tertiary boundary event and the subsequent recovery of terrestrial ecosystems. Outcrops in the basin are modest and commonly consist of temporary constructionrelated excavations. The Denver Museum of Nature \& Science has coordinated a decade-long multidisciplinary program that includes paleontological research, stratigraphic studies, aquifer analyses, and basin evolution studies in this area. As part of this effort, the synorogenic strata were continuously cored in 1999. Unusually diverse floras exhibiting rainforest physiognomy, episodic sedimentation linked to pulsed orogeny, and stratigraphic controls on aquifer distribution and quality have emerged from beneath the urbanizing landscape. Results of this work, summarized in painted reconstructions, have helped Colorado residents and museum visitors gain insight into past climates and settings, and have helped inform decisions regarding the ongoing development of the region.
\end{abstract}

\section{INTRODUCTION}

The enigmatic Laramide Orogeny can be analyzed through evaluation of the sedimentary debris shed from uplifted regions into adjacent basins. While the plate-scale genetic mechanisms responsible for the orogeny remain obscure (English and Johnston, 2004), increased precision in the analysis of synorogenic sediments can reveal patterns and trends that improve our understanding of regional tectonic development (Dickinson et al., 1988). During the Laramide Orogeny, abrupt uplift of the eastern flank of the Rocky Mountain Front Range led to the dispersal of fluvial distributary systems carrying coarse clastic debris into the asymmetrically subsiding Denver Basin (Fig. 1) on the eastern periphery of the Rocky Mountains. As the Front Range mountains rose, $>800 \mathrm{~m}$ of nonmarine strata accumulated in the basin. These sediments form the bedrock aquifers that are currently mined to supply drinking water to many communities along the Front Range urban corridor. These same rock layers are also extremely fossiliferous: almost any excavation in the rapidly urbanizing Front Range area yields exciting evidence of past flora, fauna, and landscapes. Fresh excavations are commonly only briefly available, so geological and

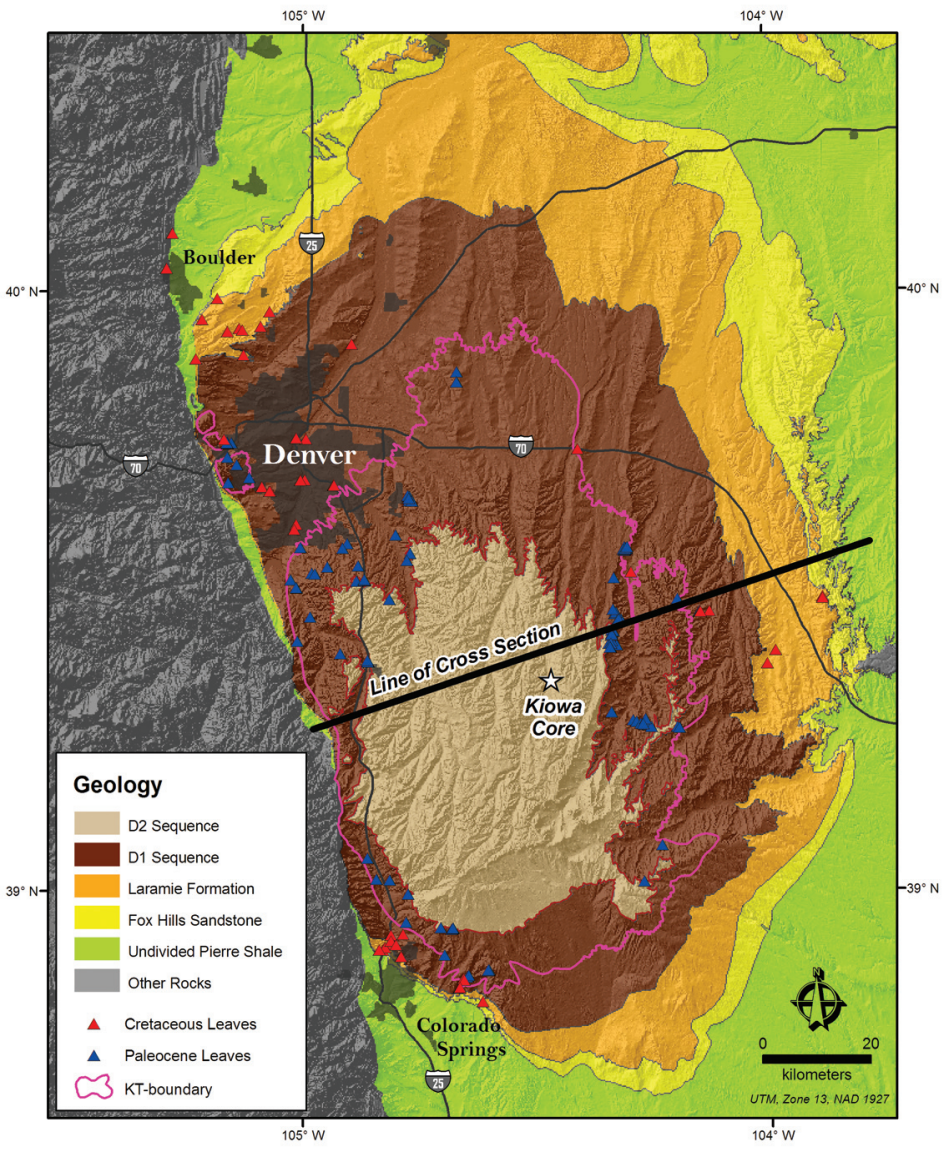

Figure 1. Geologic base map of the synorogenic strata in the Denver Basin showing fossil plant localities and the K-T boundary. This map is a compilation of over 25 geologic maps with additional boundary information obtained by intersecting three-dimensional subsurface models created by using over 1400 oil, gas, and water well electric logs with the digital elevation model. Small outcrops of post-orogenic Castle Rock Rhyolite and Castlewood Conglomerate have been omitted for clarity.

paleontological work needs to be done on an opportunistic and expedient basis. For the past decade, a team of researchers from the Denver Museum of Nature \& Science (DMNS), supported by local, state, and National Science Foundation funding, has salvaged newly discovered fossils and worked to assemble the geologic history of the Denver Basin. During the same period, Colorado's population increased by 30\%, with $80 \%$ of the state's population concentrated in the Front Range urban corridor (Mladinich, 2006).

Dinosaurs are found in people's basement excavations, and leaves from fossilized rainforests litter road cuts along busy freeways. Volcanic ash layers are found in city parks, and strati- 
graphic patterns emerge during examination of domestic and municipal water wells. The Denver Basin, while lacking the dramatic outcrops and exposures of neighboring basins, has become one of the best-documented Laramide basins because of synergy between backhoe operators, citizen scientists, and our research team.

The DMNS has catalyzed this effort by coordinating a longterm multidisciplinary research project. The goals of the project are to render accurate views of Denver Basin landscapes through time using high-resolution stratigraphy, geochronology, and paleontology. Because of the important groundwater contained in the studied rocks, we also strive to inform the hydrologic community of the resource implications of our work. With a balanced mission of noteworthy research and reaching out to and inspiring the public, the museum has made a significant effort to promote public awareness of our research results.

\section{THE KIOWA CORE, A 2256-FOOT-LONG KEY TO THE DENVER BASIN}

In 1999, we selected a location in the center of the basin near Kiowa, Colorado, and continuously cored a 2256-ft-deep well to calibrate the synorogenic stratigraphy of the basin (Fig. 2). Starting in the sagebrush, we cored down to marine strata, finding fossilized baby ammonites on split core faces in the Pierre Shale deposits of the Cretaceous Interior Seaway. The Kiowa core serves as a key for calibration of geologic studies of the Denver Basin (see the Reference section for 19 articles in Rocky Mountain Geology, v. 37 and v. 38), providing a common ground for analysis of sedimentology, palynology, isotope stratigraphy, magnetostratigraphy, petrography, thermochronology, and sedimentary provenance. The core is archived at the U.S. Geological Survey core repository in Lakewood, Colorado. Palynologic and magnetostratigraphic studies of the core, combined with ${ }^{40} \mathrm{Ar} /{ }^{39} \mathrm{Ar}$ radiometric dating of

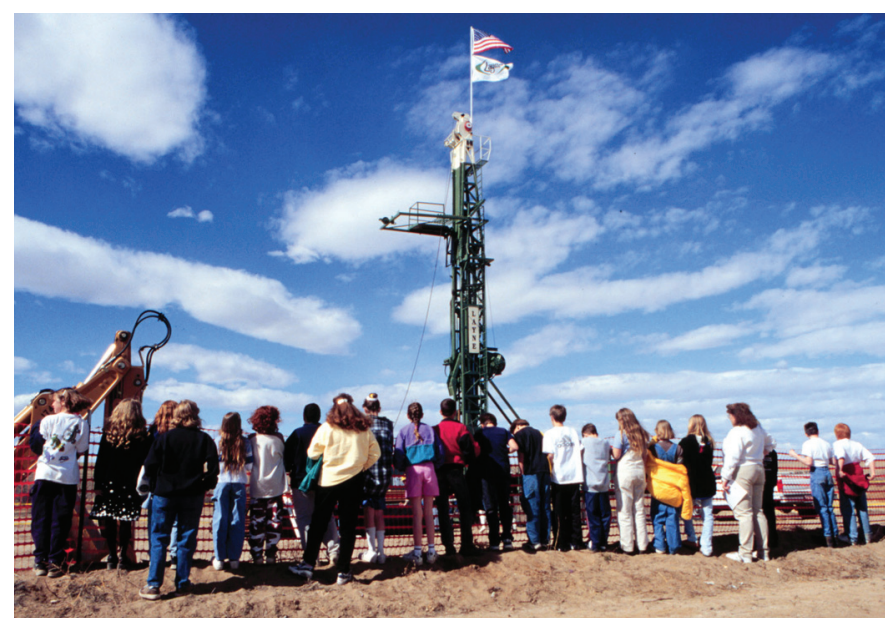

Figure 2. Drilling the Kiowa Core. The rig, operated by Layne Western, recovered over $93 \%$ of a 2.5 inch diameter core extending 2256 feet into the basin. Drilling occurred in 1999 and took seven weeks. More than 2000 visitors investigated the round-the-clock drilling operation; as the core was described, curious folks looked over our shoulders for evidence of perforated dinosaurs and other treasures. outcropping volcanic ash layers and the presence of the K-T boundary marker horizon, have allowed us to build a robust age framework for the basin (Fig. 3) (Obradovich, 2002; Nichols, 2003; Raynolds and Johnson, 2003).

We have correlated hundreds of electric logs from oil and gas test wells and water wells to the Kiowa core. This allows us to project the age framework to spotty and widely distributed outcrops at the surface. A new sequence stratigraphic framework divides the synorogenic strata (also known as the Arapahoe Conglomerate and the Denver and Dawson formations) into two unconformity-bounded sequences: D1 and D2 (Raynolds, 2002). This approach uses modern stratigraphic concepts (Miall, 1997) to cut an old Gordian knot of complex and interfingering lithostratigraphic nomenclature tied to facies and lithology (Crifasi, 1990). The D1 Sequence straddles the Cretaceous-Tertiary boundary and is unconformably overlain by the younger D2 Sequence, which was deposited during the latest Paleocene and earliest Eocene. A regional, thick oxisol (Farnham and Kraus, 2002) located near the base of the D2 Sequence may provide a record of the Paleocene-Eocene Thermal Maximum (PETM). This paleosol was recognized early on by the U.S. Geological Survey (Soister and Tschudy, 1978) and is now mapped across the basin. This weathering zone is quarried and has provided source material for the $1,400,000$ bricks used in the construction of Denver's Coors Field stadium. Today's baseball fans little realize that they are surrounded by baked clays that may have formed during an earlier episode of global warming.

Our mapping techniques are a hybrid between conventional geologic mapping and three-dimensional (3-D) modeling and geographic information system (GIS)-aided visualization.
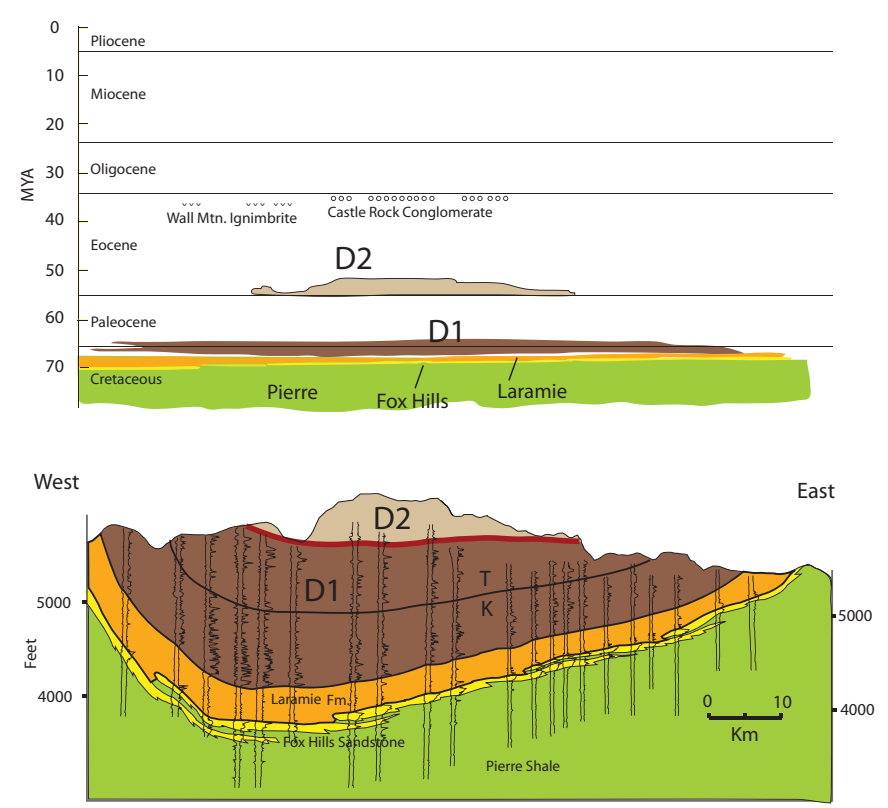

Figure 3. East to west geologic cross section of the Denver Basin with a Wheeler time diagram showing that most of geologic time is not represented by rock in this basin. The sequences of synorogenic sediment accumulated during relatively brief episodes of sedimentation and accommodation. 

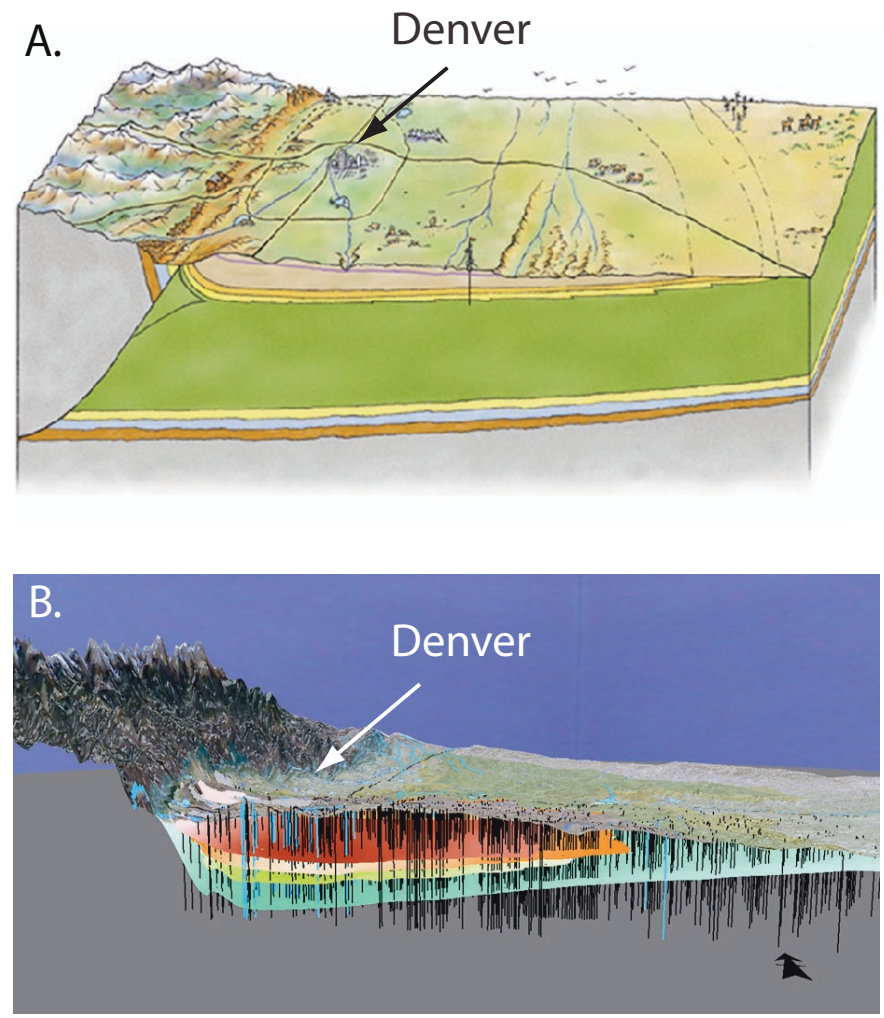

Figure 4. Three-dimensional views of strata in the Denver Basin. (A) Image (drawn by Marjorie Leggitt) is schematic; the thick green unit denotes deposits of the Cretaceous Interior Seaway. The Kiowa well is indicated by the derrick. (B) Diagram depicts a single slice taken from the threedimensional model of the basin created by using hundreds of well logs. Selected wells are indicated by vertical lines. The orange surface marks the top of the Laramie Formation, and the widespread green surface is a volcanic ash bed near the top of the Pierre Shale.

Using geological data from over 25 published geologic maps and a data set of $>1500$ wells, detailed digital 3-D models of the subsurface portion of the basin (Fig. 4) have been constructed. These models can be most compellingly viewed interactively as fly-throughs in the museum planetarium (Neafus and $\mathrm{Yu}, 2007)$. Three-dimensional visualization has helped us understand the basin geometry and has been a powerful tool for sharing insights with the public and with the local water resource planning community.

Three-dimensional models of subsurface geologic contacts coupled with digital elevation models allow us to create hybrid geologic maps that depict boundaries defined by the intersection of 3-D contacts and the land surface. This in turn allows us to map a predicted outcrop trace in areas of extensive Quaternary and suburban cover and permits precise relative stratigraphic placement and age calibration of fossils collected from isolated outcrops and construction excavations (Fig. 5).

\section{Suburban Dinosaurs and Construction Sites}

The Denver Basin strata have been yielding fossils of dinosaurs since the 1870s. The first Triceratops ever found came from a gully near the present-day site of INVESCO Field at Mile High in 1887 (Marsh, 1887). Because that specimen was

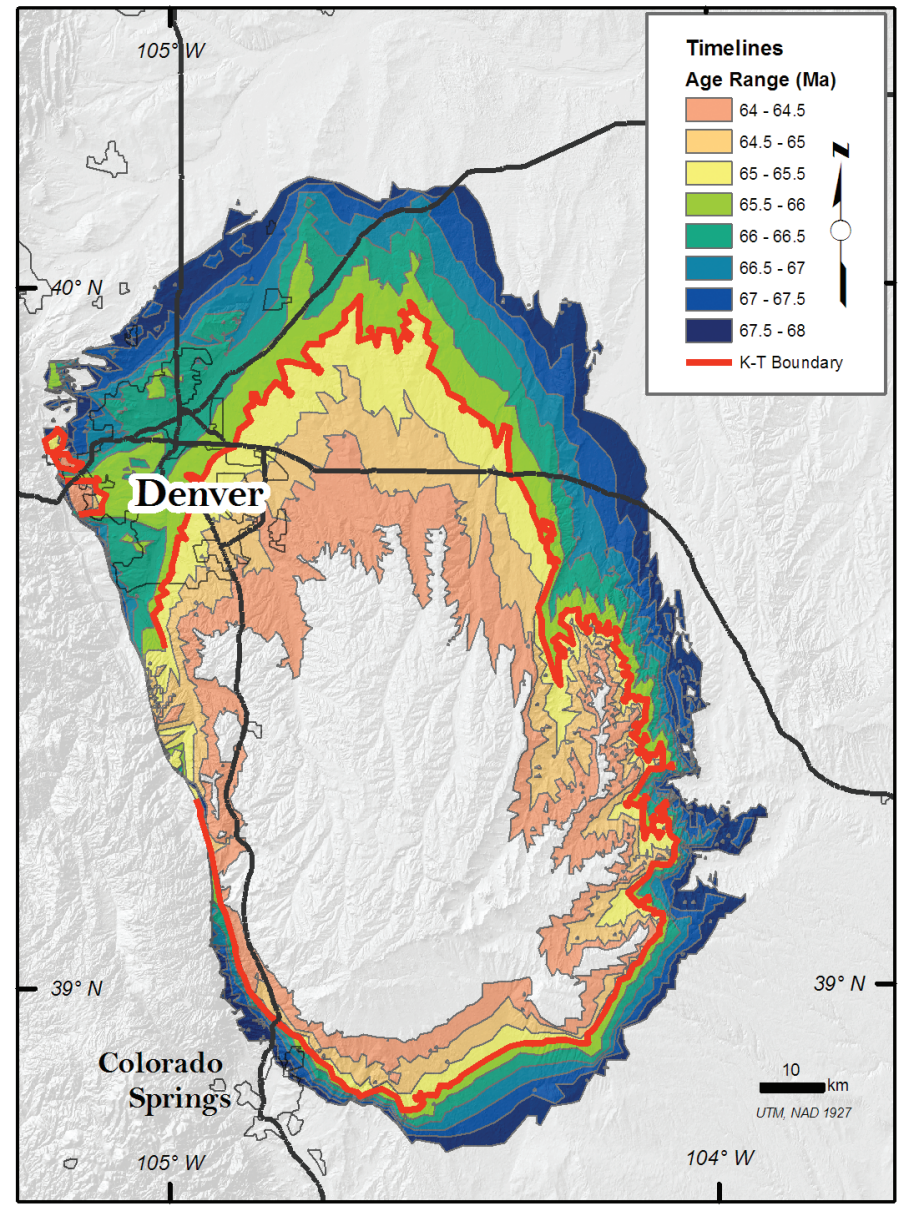

Figure 5. Map of the Denver Basin showing the age of the D1 Sequence rocks, made by assuming linear sediment accumulation rates and taking the three-dimensional rock volume models, assigning ages, and intercepting the model with the topographic surface. Red line-K-T boundary.

housed at the Smithsonian for more than a century, residents of Denver were largely unaware of their dinosaurian heritage.

Economic growth and a burgeoning population in the region led to a building boom in the 1990s. Construction sites routinely uncover dinosaur bones, which are rarely appreciated and are commonly reburied by their excavators. In 1992, a partial Tyrannosaurus rex skeleton was discovered in a home construction site in Littleton, a Denver suburb (Carpenter and Young, 2002). Using a grace period allowed by the builder, portions of the skeleton were excavated by museum staff and volunteers. A banana-sized serrated tooth from this site is one of the region's prize fossils. In 1994, an alert workman discovered palm fronds and a dinosaur rib (near home plate) during construction of Coors Field, home of the Colorado Rockies. Dinger, the Rockies' purple Triceratops mascot, was born out of the media coverage of that discovery. In 2003, Bruce Young, a DMNS volunteer, discovered a Triceratops skull on a freshly bulldozed slope in a housing development in Brighton, north of Denver (Fig. 6). A museum crew excavated the skull in less than 6 hours, and it now forms an iconic display in the Denver Museum's Prebistoric Journey exhibit. 


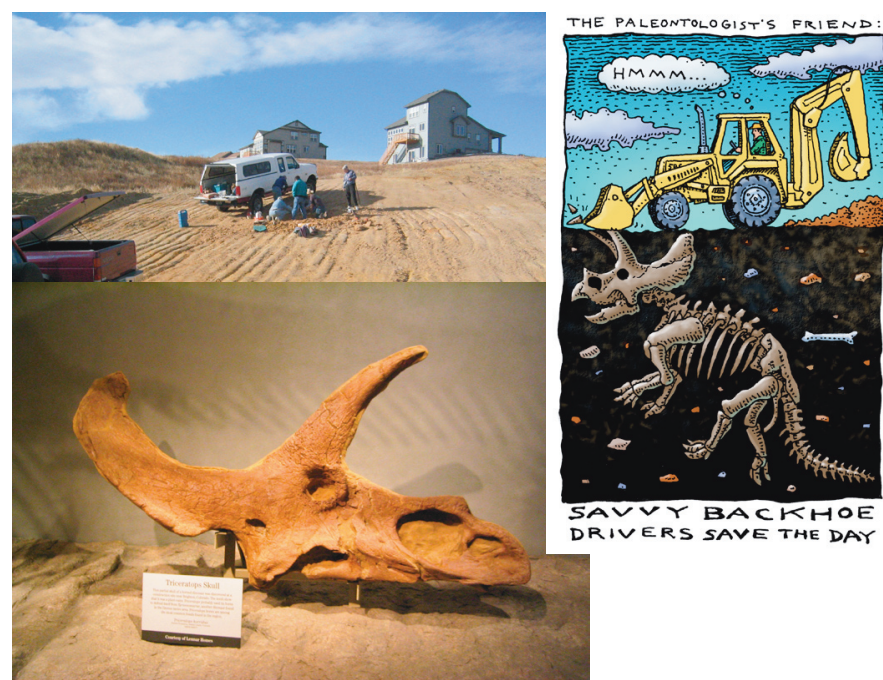

Figure 6. Top: the construction site northeast of Denver where Bruce Young discovered a Triceratops skull in 2003. The specimen is now on permanent display in Prehistoric Journey at the Denver Museum of Nature \& Science (bottom). Right: artist Ray Troll's whimsical view of the alert backhoe operator (image copyright and courtesy of Ray Troll).

\section{The Cretaceous-Tertiary Boundary and High-Resolution Geochronology}

An example of our hybrid mapping technique lies in our mapping of the outcrop pattern of the Cretaceous-Tertiary (K-T) boundary (Fig. 1). The K-T boundary was located in the Kiowa core (Nichols and Fleming, 2002), constrained by palynology, magnetostratigraphy, and the presence of anomalous iridium and shocked minerals. Using the 3-D basin model, we projected the K-T boundary to the surface (Fig. 7), where it was discovered and documented on the West Bijou Creek Escarpment (Barclay et al., 2003).

The West Bijou Creek outcrop section of the K-T boundary is marked by a distinctive 2-cm-thick claystone layer exposed in a $90-\mathrm{cm}$ lignite bed. This section is the most complete terrestrial $\mathrm{K}-\mathrm{T}$ boundary interval known. It is characterized by a full suite of K-T boundary indicators, including palynological extinction; an iridium anomaly; a shocked quartz anomaly; a fern spore spike; a carbon isotope excursion; reversed polarity (subchron C29r); Late Cretaceous vertebrates (including typical Lancian dinosaurs) and Maastrichtian plant megafossils below the boundary; and early Puercan mammals (Pu1) and basal Paleocene plant megafossils above the boundary. In addition, the 40-m section that contains the K-T boundary contains several distinctive tuff horizons that have yielded ${ }^{40} \mathrm{Ar} /{ }^{39} \mathrm{Ar}$ and $\mathrm{U}-\mathrm{Pb}$ zircon ages.

Magnetostratigraphy of D1 Sequence strata above the K-T boundary in the Kiowa core records the presence of polarity subchrons C29r, C29n, C28r, and part of C28n (Hicks et al., 2003). The exposures along the escarpment contain more than 80 discrete tuff horizons. A tuff near the top of this section has been dated at $64.13 \pm 0.21 \mathrm{Ma}$ using ${ }^{40} \mathrm{Ar} /{ }^{39} \mathrm{Ar}$ techniques (Obradovich, 2002). This series of tuff beds, deposited over a span of 1.5 m.y., offers an unprecedented opportunity to date the four basal subchrons of the Paleocene and thus provides an independent test of the magnetic polarity time scale developed in the marine realm.

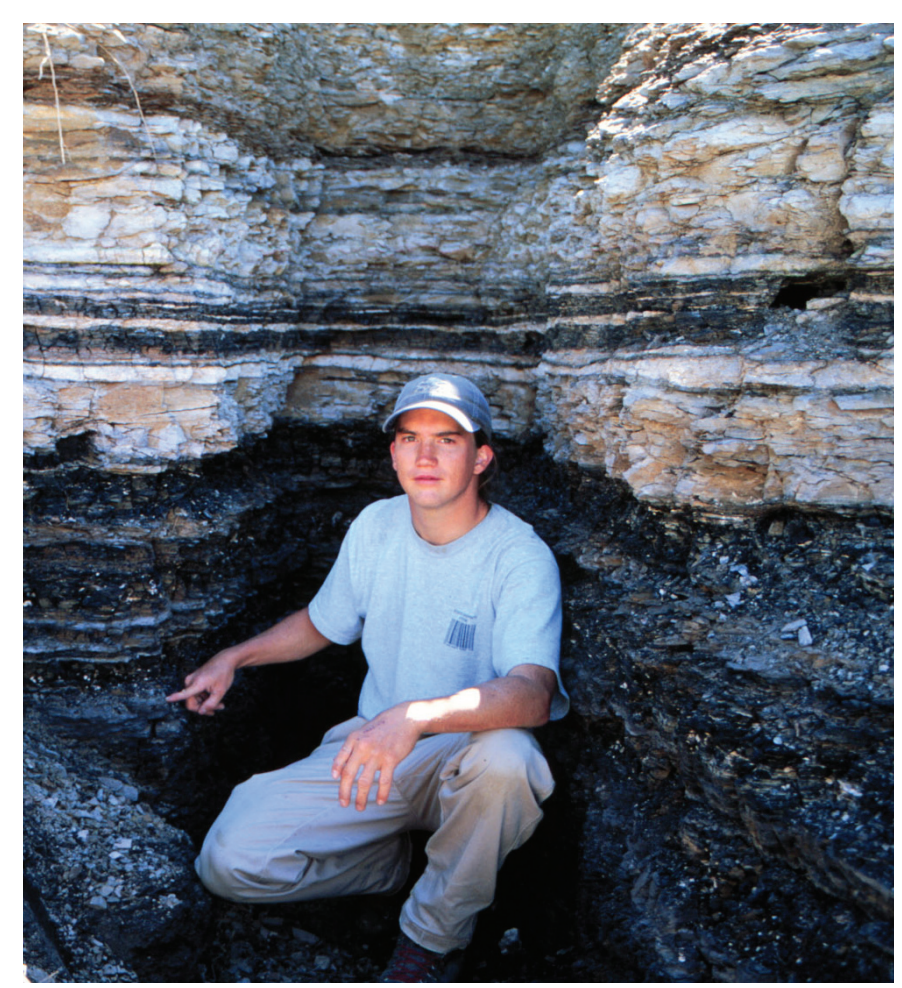

Figure 7. Rich Barclay points to the K-T boundary at a location on the Bijou Creek Escarpment east of Denver. The dark beds are lignite layers and the pale bands are volcanic ash beds suitable for both ${ }^{40} \mathrm{Ar} /{ }^{39} \mathrm{Ar}$ and $\mathrm{U}-\mathrm{Pb}$ geochronology. The K-T boundary layer is a thin $(2 \mathrm{~cm})$ gray band at the tip of Rich's index finger.

\section{Fossil Rainforests and Ancient Orography}

Fossil leaves are the most common macroscopic paleontological resource of the Denver Basin (Johnson et al., 2003). The leaves are commonly so well preserved that, when split open, leaf cuticle can be peeled off the rock. Leaf compression fossils can reveal data as detailed as the sixth-order venation patterns, and, in many cases, leaf stomata are preserved and can be studied to determine paleo- $\mathrm{CO}_{2}$ vapor pressure. The DMNS houses over 50,000 curated fossil leaves, making it one of the largest fossil leaf repositories in the world.

In 1994, Steve Wallace, a Colorado Department of Transportation paleontologist, discovered an extraordinarily diverse early Paleocene ( $63.8 \pm 0.3 \mathrm{Ma}$ ) fossil leaf site on the side of Interstate 25 in Castle Rock, Colorado, $40 \mathrm{~km}$ south of Denver and $14 \mathrm{~km}$ east of the Front Range (Johnson and Ellis, 2002; Ellis et al., 2003). DMNS teams excavated and studied over 10,000 fossil leaf specimens from this site. The Castle Rock floral assemblage is dominated by large, smooth-margined angiosperm leaves, many of which bear drip tips. Today, these types of leaves are common in tropical ever-wet rainforests. To date, the site has yielded more than 100 different species of plants, making it the most diverse Paleocene fossil plant site ever discovered. Diversity, leaf size, and taxonomic affinities of the Castle Rock site suggest that it represents a fossil tropical rainforest.

The diversity of the Castle Rock rainforest is even more remarkable because it grew $<2$ m.y. after the K-T impact event, an event marked by extinction of $\sim 60 \%$ of forest trees in the 


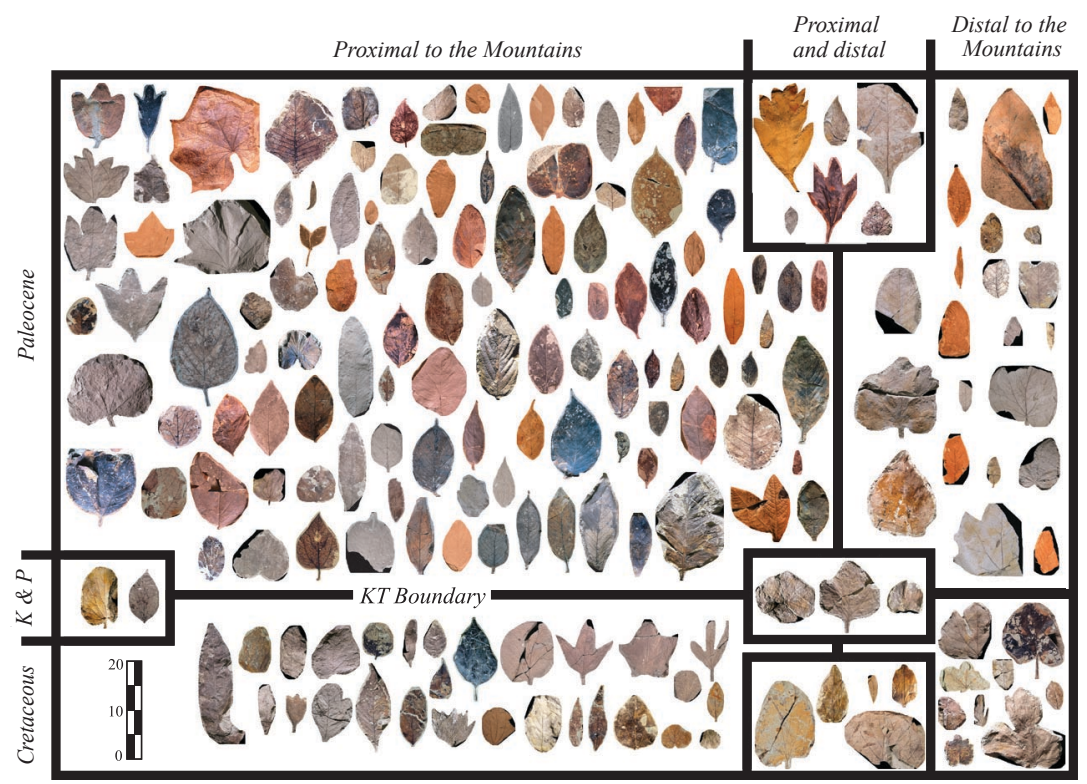

Figure 8. Space-time arrangement of fossil leaves from the Denver Basin. Each photograph depicts a different plant species at the correct relative scale. The left-hand side of the diagram shows leaves found close to the mountain front; the right side illustrates leaves found in the central and eastern portions of the basin. The abundantly populated upper left quadrant reflects the extraordinary diversity of the proximal rainforest watered by orographically controlled precipitation. Leaves in boxes are found in both adjacent areas.

Western Interior. Most Paleocene leaf sites from the Western Interior contain no more than 20 species. Based on the study of nearly 500 Paleocene sites (Brown, 1962; Hickey, 1990; Johnson, 2002; Johnson et al., 2003; Wilf, 2000), it was thought that it took 10 m.y. for ecosystems to recover from the cataclysmic K-T impact. The Castle Rock flora raises significant questions about K-T boundary recovery and the origin of tropical rainforests in general. Isotopic studies are under way to determine if ancient fractionation patterns in the canopy can be discerned to mimic those seen in modern forests.

To study the changing early Paleocene landscape and to place the Castle Rock rainforest in context, we collected an additional 10,000 fossil leaves from more than 150 Denver Basin fossil plant localities, mapped them in space and time, and tracked the appearance of individual leaf species at each locality. A clear pattern of vegetational zoning relative to the Rocky Mountain front is beginning to emerge (Fig. 8). The Castle Rock rainforest and related sites in Denver and Colorado Springs were close to the base of large alluvial fan complexes that drained the Laramide mountain range. Orographic precipitation related to the Laramide Orogeny may, therefore, be part of the Castle Rock story.
The diversity of Paleocene leaves at Castle Rock and other sites proximal to the mountain range is higher than in Paleocene sites distal to the range. Interestingly, the low-diversity distal Paleocene floras have many species in common with Western Interior Paleocene sites from Saskatchewan to New Mexico, but few species in common with the proximal Paleocene Denver Basin flora (Barclay et al., 2003). This comparison demonstrates that paleovegetation can be mapped across a paleo-altitudinal transect.

Ancient fossil rainforests spark the interest of Colorado residents who today live in an arid land, subject to water shortages, erratic rainfall, and falling aquifer levels.

\section{Groundwater for Expanding Cities from Ancient Alluvial Fans}

The poorly consolidated synorogenic sediments that fill the Denver Basin form excellent aquifers. Wells drilled into these rocks have the potential to yield up to 1000 gallons per minute of potable water. Denver's founders were keenly aware that life in the Great American Desert is tied to adequate water supplies. Early efforts secured water rights on a variety of mountain streams, including the headwaters of the Colorado River. Over the years, tunnels, canals, and reservoirs have been constructed to provide Denver, Fort Collins, Colorado Springs,

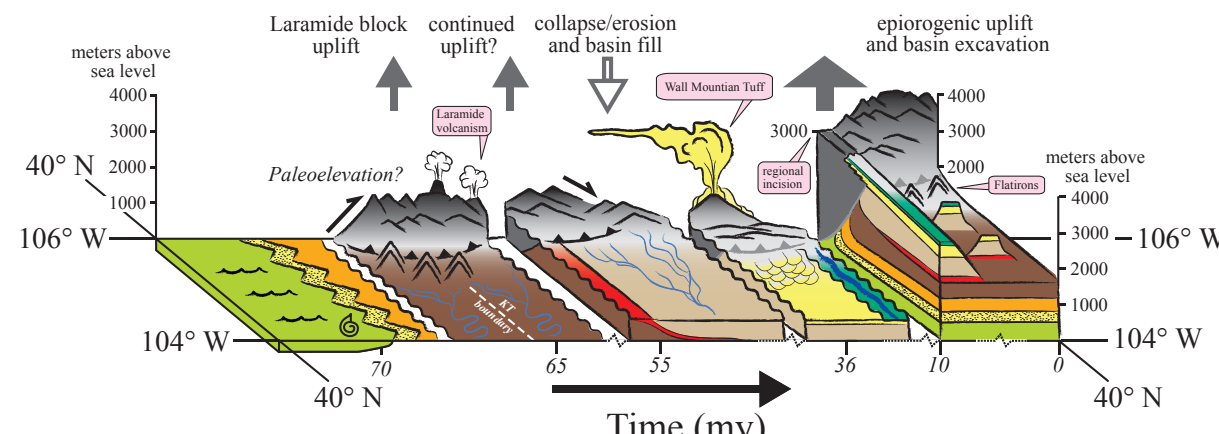

Time (my)

\begin{tabular}{cc|c|c|ccc|}
\hline & & & & & & piedmont gravels \\
\hline 70 & 60 & 50 & 40 & 30 & 20 & 10 \\
& $\square$ Fox Hills Ss & $\square$ D1 sequence & $\square$ D2 sequence & $\square$ Castle Rock Cgl \\
$\square$ Pierre Shale & $\square$ Laramie Fm & $\square$ D2 Paleosol & $\square$ Wall Mtn Tuff
\end{tabular}

Figure 9. Space-time-elevation diagram showing the evolution of topography in the Colorado Front Range and the Denver Basin. The diagram is fixed in space at latitude $40^{\circ} \mathrm{N}$ and between longitudes $104^{\circ} \mathrm{W}$ and $107^{\circ} \mathrm{W}$. It scrolls through time from $75 \mathrm{Ma}$ on the left to the present on the right, and Denver moves with time on the $x$-axis. The diagram shows the Interior Seaway and sea level conditions extending to ca. 68 Ma, followed by abrupt and episodic uplifts to the west. Between ca. 40 and $50 \mathrm{Ma}$, the area witnessed orogenic collapse and regional beveling. This was followed by late-stage regional uplift and basin exhumation. 
and Pueblo, Colorado, with a safe and adequate water supply. The Continental Divide has been tunneled through in 19 spots to divert westbound Colorado River water to these four cities along the Front Range urban corridor.

Those who came west later have had to make due with leftovers. New communities in the areas surrounding Denver and Colorado Springs commonly rely almost entirely on groundwater, because no surface-water rights are available. In fact, much of the surface-water resource is over-appropriated, meaning that in dry years, junior rights holders can be denied water, while those with older (senior) rights continue to use water. This first-come-first-served legal framework is a philosophy that has worked well for many years. Recently, drought and falling groundwater levels have caused municipal water suppliers to strive to better quantify their groundwater resources.

The Denver Basin bedrock aquifers yield Pleistocene water (Novotny and Sanford, 2004). The aquifers recharge at geologic time scales, and current utilization patterns amount to nonsustainable mining. Data published annually by the Colorado State Engineer's Office show that the water levels in many municipal wells are falling at 30-50 ft/yr (over an inch per day!) in some of the most heavily used aquifers. In the areas south of Denver, where development continues at a rapid pace and this problem is most evident, plans for alternative water supplies are under discussion, some involving interstate pipelines.

In the area west of Castle Rock and south of Denver, we have mapped a large buried fluvial distributary fan system that forms the bulk of the critical Arapahoe Aquifer (Raynolds, 2004). Analogous to large distributary fans found at the foot of the Bolivian Andes, this fan system becomes sand-poor away from the ancestral source canyon. The lithofacies distribution controls the aquifer quality and volume in the subsurface. Studies of the subsurface fan system, in conjunction with reported water-well information from the State Engineer's Office, form the basis of lifespan and performance projections of this aquifer (Raynolds, 2004). On the west side of the basin, water wells are already suffering reduced pressure heads and lower yields, and this has influenced development planning by local authorities (Douglas County Planning Commission, 2001).

\section{EVOLUTION OF THE FRONT RANGE LANDSCAPE}

The Denver Basin strata can be used to deduce changes in regional landscapes and topography (Fig. 9), helping to clarify a piece of the Laramide puzzle. The region formed part of the floor of the Western Interior Seaway for 30 m.y. in the Late Cretaceous. Marine fossils in the Pierre Shale demonstrate that the region remained below sea level until ca. $69 \mathrm{Ma}$, the approximate age of the ammonite Baculites clinolobatus (Cobban et al., 2006). A series of off-lapping regressive sandstone shingles overlie the Pierre Shale and make up the Fox Hills Sandstone (Fig. 9). The Fox Hills Sandstone is in turn overlain by coastal swamp deposits that comprise the Laramie Formation. The Laramie Formation thickens westward toward the mountain front, suggesting that a gentle sag presaged the Laramide uplift of the Front Range.

An unconformity representing erosion or absence of deposition separates the Laramie Formation from the overlying D1 Sequence. This unconformity is indicated by abrupt facies change: gravels and conglomerates overlie a weakly incised shale-rich Laramie section. The amount of time not represented by rock is probably $<1$ m.y. because the extrapolated age of the base of the D1 Sequence-based on assumptions of uniform rates of sediment accumulation - is $68 \mathrm{Ma}$, only a million years younger than the youngest dated marine faunas in the underlying Pierre Shale. We suggest the basin area was near sea level as these events were taking place, based on the swampy character of the Laramie Formation over large areas, including west of the present Denver Basin, in South Park, Colorado (Washborne, 1910).

The 68 Ma Arapahoe Conglomerate forms the basal unit of the D1 Sequence. It contains clasts of chert, quartzite, and petrified wood derived from Paleozoic and Mesozoic sedimentary sequences together with metamorphic and igneous clasts derived from Precambrian crystalline rocks. This requires that significant topographic relief developed in the source region with incision depths of at least $3 \mathrm{~km}$.

The overlying andesitic facies and numerous volcanic ash horizons provide a record of Laramide volcanism in the Colorado Front Range. The volcanoes have been eroded away; their existence is documented only by volcaniclastic debris in the Denver, South Park, and Middle Park basins (Raynolds, 2003; Izett, 1968). By $64 \mathrm{Ma}$, rainforests characterized by diverse assemblages of angiosperms with large, smooth-margined leaves dominated the eastern flank of the Front Range, providing a record of early Tertiary orographic precipitation.

An unconformity representing an 8 m.y. depositional hiatus or an episode of erosion separates the top of the D1 Sequence from the overlying arkosic D2 Sequence. The duration of deposition of the D2 Sequence is unknown. Rocks with apatite grains dating in excess of $100 \mathrm{Ma}$ are found in the Front Range (Kelley, 2002), so we know that incision following the Laramide uplift was not sufficient to cut down to rocks heated sufficiently to anneal the fission tracks.

At 36.7 Ma (McIntosh and Chapin, 1994), the Wall Mountain Tuff erupted across the beveled Rocky Mountain Surface (Epis and Chapin, 1975), demonstrating that, by this time, topography had equilibrated between the range and the basin. Following its emplacement, the Wall Mountain Tuff was incised. Paleocanyons cut into this formation are filled and overtopped by the Castle Rock Conglomerate, a rock unit that contains angular rhyolite clasts in excess of a meter in diameter.

Epirogenic uplift of the High Plains together with the Front Range region occurred roughly between $10 \mathrm{Ma}$ and the present, triggering widespread incision (McMillan et al., 2006). Differential uplift between the plains and the range is negligible because the Rocky Mountain Surface, which is preserved in the basin by buttes capped by the Wall Mountain Tuff, lies on the same gentle slope, defining a ramp between the basin and the range (Leonard and Langford, 1994). Miocene and later regional uplift first led to the dispersal of a widespread conglomeratic facies (the Ogallala Group), then to basin exhumation and renewed bedrock incision by the headward erosion of the tributaries to the Mississippi river system. Thus, the present relative relief of the Front Range is a function of differential erosion, not uplift.

\section{SHARING SCIENCE WITH FRONT RANGE CITIZENS}

Working with artist Jan Vriesen, and funded by the city of Denver's One Percent for Art Program, we have used paleobotanical and paleogeographic information to reconstitute long-gone vistas as ten Ancient Colorado paintings that grace the Colorado 
Convention Center. Other paintings by Vriesen, Donna Braginetz, and Gary Staab are on display in the Ancient Denvers exhibit at the DMNS (see www.dmns.org/main/minisites/ancientDenvers/ index.html), in a popular book of the same title (Johnson and Raynolds, 2002), at the Denver International Airport, and in parks and open space venues throughout the region.

The DMNS plays a key role in public education in the Rocky Mountain region. A particularly critical product of the stratigraphic work has been the evaluation of the regional groundwater potential of the basin-filling sediments. This applied research fulfills a museum goal to emphasize locally derived and relevant information and to make the results of ongoing research available in a variety of formats to both our membership and the community. By involving teams of volunteers in the research, we help bring the excitement of this quest into the everyday lives of lay citizens. We have hosted lecture series and roundtables and sent representatives to speak at state legislative events and city council and regional water forums in order to educate policymakers. Sarah Andrews cast the research into a forensic geology novel in 2005.

The extraordinary diversity of ancient landscapes brought to life through these efforts of data gathering, analysis, and depiction help Denver residents place the present in the context of the past. A population with an appreciation of the ever-changing face of the land will be better positioned to evaluate issues of change that lie ahead.

\section{ACKNOWLEDGMENTS}

Reviews by Octavian Catuneanu, David Fastovsky, Craig Jones, and an anonymous reviewer considerably improved the manuscript. Extended efforts and comments by editor Stephen Johnston brought focus and were most useful. This work was funded in part by National Science Foundation grant EAR-0345910.

\section{REFERENCES CITED}

Andrews, S., 2005, Dead Dry: New York, St. Martin's Press, 368 p.

Barclay, R.S., Johnson, K.R., Betterton, W.J., and Dilcher, D.L., 2003, Stratigraphy and megaflora of a K-T boundary section in the eastern Denver Basin, Colorado: Rocky Mountain Geology, v. 38, p. 45-71, doi: 10.2113/gsrocky.38.1.45.

Brown, R., 1962, Paleocene flora of the Rocky Mountains and Great Plains: U.S. Geological Survey Professional Paper 375, 119 p.

Carpenter, K., and Young, D.B., 2002, Late Cretaceous dinosaurs from the Denver Basin, Colorado: Rocky Mountain Geology, v. 37, p. 237-254.

Cobban, W.A., Walaszcyk, I., Obradovich, J.D., and McKinney, K.C., 2006, A USGS zonal table for the Upper Cretaceous Middle Cenomanian-Maastrichtian of the Western Interior of the United States based in Ammonites, inoceramids, and radiometric dates: U.S. Geological Survey Open File Report 2006-1250, 114 p.

Crifasi, R.R., 1990, Stratigraphic nomenclature inconsistencies in Laramide orogenic sediments; Denver Basin, Colorado: Proceedings of the groundwater management and engineering conference, Colorado Water Resources Research Institute, Fort Collins, p. 407-424.

Dickinson, W.R., Klute, M.A., Hayes, M.J., Janecke, S.U., Lundin, E.R., McKitrick, M.A., and Olivares, M.D., 1988, Paleogeographic and paleotectonic setting of Laramide sedimentary basins in the central Rocky Mountain region: Geological Society of America Bulletin, v. 100, p. 1023-1039, doi: 10.1130/00167606(1988)100<1023:PAPSOL >2.3.CO;2.

Douglas County Planning Commission, 2001, Douglas County 2020 comprehensive master plan: Douglas County Community Development Planning Division, Section 9, Water Supply, p. 9.1-9.17.

Ellis, B., Johnson, K.R., and Dunn, R.E., 2003, Evidence for an in situ early Paleocene rainforest from Castle Rock, Colorado: Rocky Mountain Geology, v. 38, p. 73100, doi: 10.2113/gsrocky.38.1.173

English, J.M., and Johnston, S.T., 2004, The Laramide Orogeny: What were the driving forces?: International Geology Review, v. 46, p. 833-838.

Epis, R.C., and Chapin, C.E., 1975, Geomorphic and tectonic implications of the post Laramide, Late Eocene erosion surface in the southern Rocky Mountains, in Curtis, B.F., ed., Cenozoic history of the southern Rocky Mountains: Geological Society of America Memoir 144, p. 45-74.

Farnham, T.M., and Kraus, M.J., 2002, The stratigraphic and climatic significance of Paleogene alluvial paleosols in synorogenic strata of the Denver Basin, Colorado: Rocky Mountain Geology, v. 37, p. 201-213.
Hickey, L.J., 1990, Paleocene stratigraphy and flora of the Clark's Fork Basin, in Gingrich, P.D., ed., Early Cenozoic paleontology and stratigraphy of the Bighorn Basin, Wyoming: Ann Arbor, University of Michigan Papers on Paleontology, v. 24, p. 33049.

Hicks, J.F., Johnson, K.R., Obradovich, J.D., Miggins, D.P., and Tauxe, L., 2003, Magnetostratigraphy of Upper Cretaceous (Maastrichtian) to lower Eocene strata of the Denver Basin, Colorado: Rocky Mountain Geology, v. 38, p. 1-27, doi: 10.2113/gsrocky.38.1.1.

Izett, G.A., 1968, Geology of the Hot Sulphur Springs quadrangle, Grand County, Colorado: U.S. Geological Survey Professional Paper 586, 79 p.

Johnson, K.R., 2002, The megaflora of the Hell Creek and lower Fort Union formations in the western Dakotas: Vegetational response to climate change, the CretaceousTertiary boundary event, and rapid marine transgression, in Hartman, J., Johnson, K.R., and Nichols, D.J., eds., The Hell Creek Formation and the Cretaceous Tertiary boundary in the northern Great Plains: An integrated continental record of the end of the Cretaceous: Geological Society of America Special Paper 361, p. 329-392.

Johnson, K.R., and Ellis, B., 2002, A tropical rainforest in Colorado 1.4 million years after the Cretaceous-Tertiary boundary: Science, v. 296, p. 2379-2383, doi: 10.1126/science.1072102.

Johnson, K.R., and Raynolds, R.G., 2002, Ancient Denvers: Scenes from the past 300 million years of the Colorado Front Range: Denver Museum of Nature \& Science Press, $34 \mathrm{p}$.

Johnson, K.R., Reynolds, M.L., Werth, K.W., and Thomasson, J.R., 2003, Overview of the Late Cretaceous, early Paleocene, and early Eocene megaflora of the Denver Basin, Colorado: Rocky Mountain Geology, v. 38, p. 101-120, doi: 10.2113/ gsrocky.38.1.101.

Kelley, S.A., 2002, Unroofing of the southern Front Range, Colorado: A view from the Denver Basin: Rocky Mountain Geology, v. 37, p. 189-200.

Leonard, E.M., and Langford, R.P., 1994, Post-Laramide deformation along the eastern margin of the Colorado Front Range-a case against significant faulting: The Mountain Geologist, v. 31, p. 45-52.

Marsh, O.C., 1887, Notice on some new fossil mammals: American Journal of Science, v. 34, p. 323-324.

McIntosh, W.C., and Chapin, C.E., $1994,{ }^{40} \mathrm{Ar} /{ }^{39} \mathrm{Ar}$ geochronology of ignimbrites in the Thirtynine MileVolcanic Field, Colorado, in Evanoff, E., ed., Late Paleogene geology and paleoenvironments of Central Colorado: Boulder, Colorado, Geological Society of America Field Trip Guidebook, p. 23-26.

McMillan, M.E., Heller, P.L., and Wing, S.L., 2006, History and causes of post-Laramide relief in the Rocky Mountain orogenic plateau: Geological Society of America Bulletin, v. 118, p. 393-405, doi: 10.1130/B25712.1.

Miall, A.D., 1997, The geology of stratigraphic sequences: Berlin, Springer, 433 p.

Mladinich, C.S., 2006, Regional landscape change in northeastern Colorado Front Range: U.S. Geological Survey Professional Paper 1726, p. 139-152.

Neafus, D., and Yu, KaChun, 2007, The digital Gates Planetarium at the four year mark: Innovations and adventures of a fulldome theater: The Planetarian (in press).

Nichols, D.J., 2003, Palynostratigraphic framework for age determination and correlation of the non-marine Lower Cenozoic of the Rocky Mountains and Great Plains Region, in Raynolds, R.G., and Flores, R.M., eds., Cenozoic Systems of the Rocky Mountain Region: Denver, Colorado, Society for Sedimentary Geology (SEPM), p. 107-134.

Nichols, D.J., and Fleming, R.F., 2002, Palynology and palynostratigraphy of Maastrichtian, Paleocene, and Eocene strata in the Denver Basin, Colorado: Rocky Mountain Geology, v. 37, p. 135-163.

Novotny, M., and Sanford, W., 2004, Groundwater residence time and recharge temperature estimates of the Denver and Arapahoe aquifers, Denver Basin, Colorado: The Mountain Geologist, v. 41, p. 161-168.

Obradovich, J.D., 2002, Geochronology of Laramide synorogenic strata in the Denver Basin, Colorado: Rocky Mountain Geology, v. 37, p. 165-171.

Raynolds, R.G., 2002, Upper Cretaceous and Tertiary stratigraphy of the Denver Basin, Colorado: Rocky Mountain Geology, v. 37, p. 111-134.

Raynolds, R.G., 2003, Laramide synorogenic strata bounding the Front Range, Colorado, in Raynolds, R.G., and Flores, R.M., eds., Cenozoic Systems of the Rocky Mountain Region: Denver, Colorado, Society for Sedimentary Geology (SEPM), p. 355-368.

Raynolds, R.G., 2004, Stratigraphy and water levels in the Arapahoe Aquifer, Douglas County area, Denver Basin, Colorado: The Mountain Geologist, v. 41, p. 195210.

Raynolds, R.G., and Johnson, K.R., 2003, Synopsis of the stratigraphy and paleontology of the uppermost Cretaceous and lower Tertiary strata in the Denver Basin, Colorado: Rocky Mountain Geology, v. 38, p. 171-181, doi: 10.2113/ gsrocky.38.1.171.

Soister, P.E., and Tschudy, R.H., 1978, Eocene rocks in Denver Basin, in Pruit, J.D., and Coffin, P.E., eds., Energy Resources in the Denver Basin: Rocky Mountain Association of Geologists Symposium, p. 231-235.

Washborne, C.W., 1910, The South Park coal field, Colorado: U.S. Geological Survey Bulletin 381-C, p. 307-316.

Wilf, P., 2000, Late Paleocene-early Eocene climate changes in southwestern Wyoming: Paleobotanical analysis: Geological Society of America Bulletin, v. 112, p. 292307, doi: 10.1130/0016-7606(2000)112<0292:LPEECC>2.3.CO;2.

Manuscript received 23 May 2007; accepted 3 September 2007. 